\title{
The parasitic tick Ixodes uriae (Acari: Ixodidae) on seabirds from Spitsbergen, Svalbard
}

\author{
Stephen James Coulson, ${ }^{1}$ Erlend Lorentzen, ${ }^{2}$ Hallvard Strøm ${ }^{2}$ \& Geir Wing Gabrielsen ${ }^{2}$ \\ 1 Department of Arctic Biology, University Centre in Svalbard, NO-9171 Longyearbyen, Norway \\ 2 Norwegian Polar Institute, Polar Environmental Centre, NO-9296 Tromsø, Norway
}

\section{Keywords}

Guillemot; Ixodes; Spitsbergen.

\section{Correspondence}

S.J. Coulson, Department of Arctic Biology, University Centre in Svalbard, P.O. Box 156, NO-9171 Longyearbyen, Svalbard, Norway. E-mail: steve.coulson@unis.no

doi:10.1111/j.1751-8369.2009.00117.x

\begin{abstract}
The parasitic tick Ixodes uriae was recorded from Brünnich's guillemots (Uria lomvia) at two colonies on Spitsbergen, the principal island in the Arctic archipelago of Svalbard. Six Brünnich's guillemots from 30 studied at the Ossian Sars seabird colony were found to be parasitized. A tick was also collected from below the larger Fuglehuken colony. However, ticks were not seen on Brünnich's guillemots examined at the smaller Krossfjorden colony, and neither were they observed in two black-legged kittiwake (Rissa tridactyla) colonies (Blomstrandhalvøya and Krykkjefjellet). It is suggested that either the tick has only recently been established in Svalbard or the population has increased from a low level, and has consequently become visible to small-scale sampling studies. Implications for the seabird population of the northern Barents Sea are discussed.
\end{abstract}

The bird tick Ixodes uriae (White, 1852) (Acari: Ixodidae) is a common ectoparasite of many species of colonial seabird and, although displaying local adaptation to its seabird host, has a circumpolar distribution in both the Arctic and Antarctic (McCoy et al. 2005). The tick is known from Bjørnøya (Bear Island), the southern outlying island of the Svalbard Archipelago, where it was first observed in 2002 on common guillemot (Uria aalge). It is likely that the tick is also present on Brünnich's guillemot (Uria lomvia) and glaucous gull (Larus hyperboreus) from Bjørnøya (H. Strøm, unpubl. data). The tick had previously only been observed once in the main part of the Svalbard Archipelago, with one larva being found on a black-legged kittiwake (Rissa tridactyla) from the 61 blacklegged kittiwake and six Brünnich's guillemot chicks searched at Ossian Sarsfjellet, on the island of Spitsbergen, in 1999 (McCoy 2001). With this exception, the tick has not been recorded on seabirds from Spitsbergen (G.W. Gabrielsen, pers. obs.; Coulson 2007). Indeed, although they may harbour a range of Mallophaga (Mehl et al. 1982) and parasitic gut nematodes (Sagerup et al. 2000), the majority of the seabirds on Spitsbergen are relatively clean of ectoparasites.

Of the 28 species of bird that breed regularly in Svalbard (Strøm \& Bangjord 2004), the Brünnich's guillemot is one of the most numerous, and has a wide circumpolar distribution, occurring at latitudes between 46 and $82^{\circ} \mathrm{N}$ (Strøm 2006). Breeding takes place on cliff ledges, and Brünnich's guillemot colonies in Svalbard can attain a population of more than 100000 pairs (Strøm 2006).

Infestation with I. uriae may have debilitating effects on the host, including acting as a vector for several viral and bacterial pathogens (Nunn et al. 2006; Larsson et al. 2007; Staszewski et al. 2007), reduction of host haematocrit (Wanless et al. 1997) and sub-lethal behavioural changes (Boulinier \& Danchin 1996; Mangin et al. 2003). These effects influence the population dynamics of the seabirds, and hence the presence of I. uriae on Spitsbergen is important for the seabird ecology of the northern Barents region.

\section{Materials and methods}

During July 2007, Brünnich's guillemots and blacklegged kittiwakes from the Kongsfjorden region of Spitsbergen (Fig. 1) were hand-searched for ticks. Spitsbergen, approximately $76.5-80^{\circ} \mathrm{N}, 10-21^{\circ} \mathrm{E}$, is the main island of the Svalbard Archipelago. Brünnich's guillemots were examined from four colonies, two close to the settlement of Ny-Ålesund, one from Ossian Sars and one from Krossfjorden, in the vicinity of Flakbreen (Fig. 1). In addition, birds were observed from a distance at 


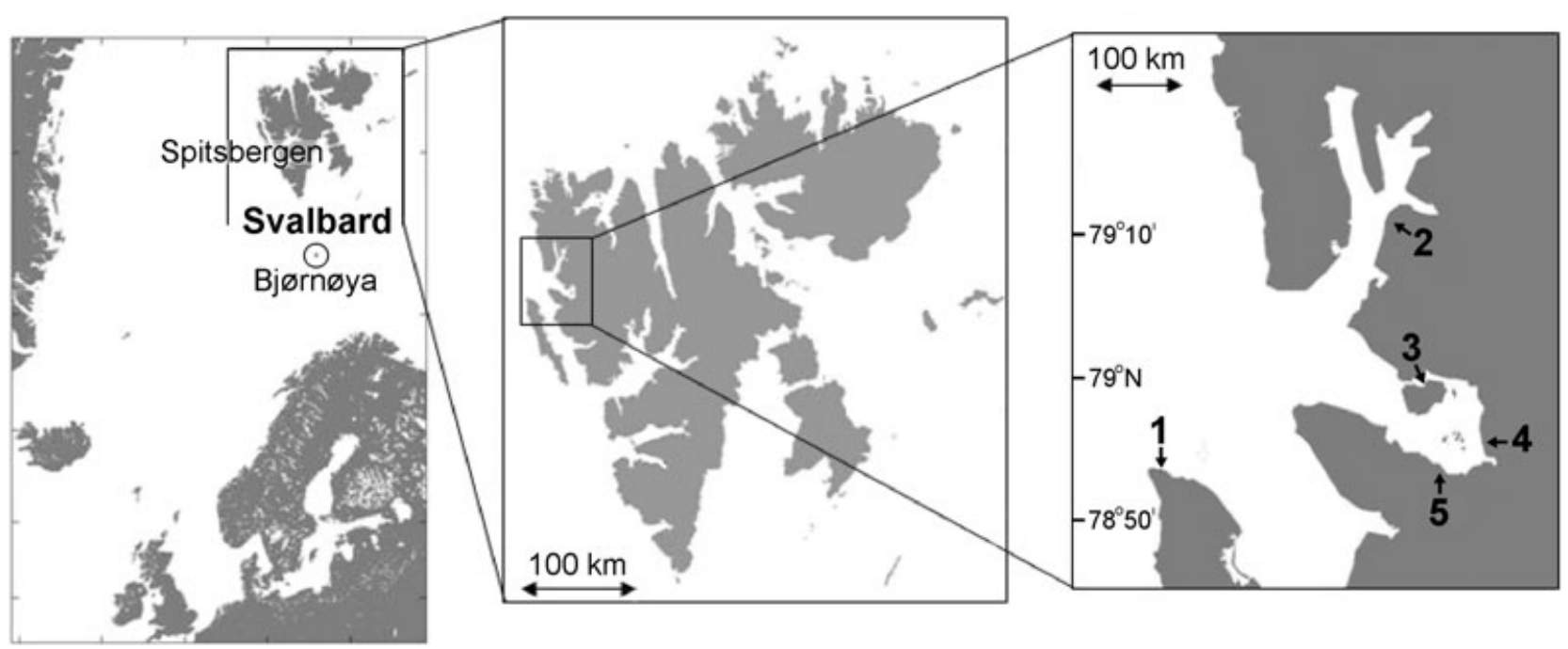

Fig. 1 Location of the colonies sampled on Spitsbergen, Svalbard: (1) Fuglehuken; (2) Krossfjorden, in the vicinity of Flakbreen; (3) Blomstrandhalvøya; (4) Ossian Sars; and (5) Krykkjefjellet.

Table 1 Summary of the colonies studied (data from this study or SCRIB 2007). (+ = present but in low numbers)

\begin{tabular}{|c|c|c|c|c|c|c|c|c|}
\hline Colony & Location & $\begin{array}{l}\text { Number of } \\
\text { Brünnich's } \\
\text { guillemots }\end{array}$ & $\begin{array}{l}\text { Number of } \\
\text { black-legged } \\
\text { kittiwakes. } \\
\text { (breeding pairs) }\end{array}$ & $\begin{array}{l}\text { Number of } \\
\text { little auks }\end{array}$ & $\begin{array}{l}\text { Number of } \\
\text { Atlantic } \\
\text { puffins }\end{array}$ & $\begin{array}{l}\text { Number of } \\
\text { common } \\
\text { guillemots }\end{array}$ & $\begin{array}{l}\text { Number } \\
\text { of birds } \\
\text { searched }\end{array}$ & $\begin{array}{l}\text { Birds } \\
\text { infested } \\
(\%)\end{array}$ \\
\hline Fuglehuken & $78^{\circ} 53^{\prime} \mathrm{N}, 10^{\circ} 32^{\prime} \mathrm{E}$ & 50000 & 4000 & Present $^{a}$ & Present $^{a}$ & Present $^{\mathrm{a}}$ & 0 & $0^{b}$ \\
\hline Krossfjorden & $79^{\circ} 09^{\prime} \mathrm{N}, 11^{\circ} 51^{\prime} \mathrm{E}$ & 220 & & & & & 39 & 0 \\
\hline Ossian Sars & $78^{\circ} 56^{\prime} \mathrm{N}, 12^{\circ} 29^{\prime} \mathrm{E}$ & 1100 & 1300 & & & & 30 & 20 \\
\hline Blomstrand-halvøya & $78^{\circ} 59^{\prime} \mathrm{N}, 12^{\circ} 08^{\prime} \mathrm{E}$ & & 966 & & & & 30 & 0 \\
\hline Krykkjefjellet & $78^{\circ} 54^{\prime} \mathrm{N}, 12^{\circ} 12^{\prime} \mathrm{E}$ & & 637 & & & & 30 & 0 \\
\hline
\end{tabular}

apresent, but in low numbers.

${ }^{b}$ One tick collected from under the birdcliffs.

Fuglehuken. Black-legged kittiwakes were examined from two colonies in Kongsfjorden: Blomstrandhalvøya and Krykkjefjellet (Fig. 1).

The Brünnich's guillemot colonies at Ossian Sars (1100 individuals; Table 1; SCRIB 2007) and Fuglehuken (50 000 individuals) are considerably larger than the Krossfjorden colony, where the population is estimated to be 220 individuals. Moreover, at Fuglehuken, there are also 4000 pairs of black-legged kittiwakes (SCRIB 2007), as well as small numbers of northern fulmars (Fulmarus glacialis), common guillemots, common eiders (Somateria mollissima), little auks (Alle alle), Atlantic puffins (Fratercula arctica), glaucous gulls, Arctic skuas (Stercocarius parasiticus) and barnacle and pink-footed geese (Branta leucopsis and Anser brachyrhynchus). At Ossian Sars, blacklegged kittiwakes are present in addition to Brünnich's guillemots (SCRIB 2007). The two black-legged kittiwake colonies searched are also small, with Blomstrandhalvøya and Krykkjefjellet having ca. 966 and 637 pairs, respectively (SCRIB 2007; Table 1).
Searching seabirds for ticks was undertaken in conjunction with other projects, and, initially, birds were not captured specifically to assess parasite prevalence. On 6 and 7 July 2007, 30 Brünnich's guillemots from the Ossian Sars colony were hand-searched for ticks. The life stages of the feeding ticks were not recorded. At Krossfjorden, 39 Brünnich's guillemots were caught. Ten birds (six males and four females) were searched systematically, whereas the remaining 29 birds were subject to a brief inspection for ticks. Engorged adult ticks are readily observed, even under plumage, because of their large size.

Black-legged kittiwakes, both adults and chicks (30 individuals per colony), were also searched during the same field season from colonies at Krykkjefjellet and Blomstrandhalvøya.

\section{Results}

Six Brünnich's guillemots from the Ossian Sars colony were infested by feeding ticks (Table 1), mostly at the top 
of the legs. At Fuglehuken, one live, fully engorged tick was collected fortuitously from grass under these bird cliffs on 23 June 2007. No ticks were found at the Krossfjorden, Blomstrandhalvøya or Krykkjefjellet colonies.

\section{Discussion}

The seabird colonies of Kongsfjorden, Svalbard, have been studied in detail since the early 1980s. Nonetheless, previous studies involving the direct handling of the seabirds failed to detect the presence of I. uriae, with the exception of that of McCoy (2001), who, after examining 61 blacklegged kittiwakes at Ossian Sarsfjellet, found one larva on a chick, in 1999. In the summer of 2007, I. uriae was observed in the two larger Brünnich's guillemot colonies of the three colonies studied. The age of a colony has been implicated in the level of infestation by I. uriae (Danchin 1992), but this seems unlikely to be of importance here, as all the colonies in the present study were well established. However, it has also been previously observed that parasite density can vary greatly, even within a colony (McCoy et al. 2003), and it may be that the presence of the tick at Krossfjorden was overlooked because of the limited sampling. No black-legged kittiwakes, adults or chicks, were seen to be parasitized at the two colonies studied.

The presence of I. uriae on Spitsbergen may have debilitating consequences for the seabird population of the northern Barents. For example, the feeding of the tick is known to reduce the haematocrit (Wanless et al. 1997), and it has been suggested that during extreme infestations, the loss of blood can lead to the death of the host (Gauthier-Clerc et al. 1998). I. uriae may also have sublethal behavioural effects that result in reduced breeding success (Mangin et al. 2003). High levels of infestation result in black-legged kittiwakes abandoning historical breeding sites and founding new colonies (Boulinier \& Danchin 1996), but these new colonies may be at less favourable locations, thereby reducing the overall fitness of the colony. Seabirds in the Arctic may already be under significant levels of stress, resulting from the lack of food, pollutants and climate change (Sagerup et al. 2000; Gabrielsen 2007; Sandvik et al. 2005); any additional stress factor may exacerbate the existing effects, with unpredictable results on seabird populations.

Ixodes uriae occurs throughout the seabird colonies of Norway (Mehl \& Traavik 1983), and it is interesting to ask why I. uriae is now being observed on Spitsbergen. There are several possible answers. (i) The tick has always been present, but not previously observed. Despite seabirds being handled every year since the early 1980s, in studies often involving ringing and blood sampling, as well as in investigations aimed at detecting the tick, I. uriae has only once been recorded previously on Spitsbergen (McCoy
2001). If the tick was resident previously, its density must have been low, and we are now observing an increasing population. Nonetheless, it must be recognized that only one study has previously been targeted at collecting ticks (McCoy 2001), and because of the difficulties in sampling birds in Svalbard, only a limited number of individuals were searched. (ii) The levels of persistent organic pollutants are rising. Persistent organic pollutant (POP) levels in many populations of Arctic seabirds are rising (Gabrielsen 2007), and this has a negative effect on their immune systems, resulting in an elevated gut parasite load (Sagerup et al. 2000). Given that the immune response restricts tick development by impairing engorgement, ova production and viability (Wikel 1996), increased POPs may result in greater $I$. uriae infestation rates among Arctic seabirds. (iii) Ticks were introduced by birds from other colonies. Infested prospecting birds may recently have moved north, bringing the tick with them. (iv) Climate change enables ticks to survive the winter. I. uriae is thought to be freezing intolerant, and, with the exception of the egg stage, cannot survive temperatures below $-12{ }^{\circ} \mathrm{C}$ (Lee \& Baust 1987). The recent relatively mild winters, with no sea-ice formation in Kongsfjorden, may have enabled greater overwintering success.

In conclusion, the bird tick I. uriae has recently been observed on Brünnich's guillemots on Spitsbergen. If it is a new arrival, it may spread to other breeding bird species and populations, and is likely to affect the ecology of the seabird population in the northern Barents Sea. Further studies that examine Svalbard seabirds for this parasite are called for.

\section{Acknowledgements}

The authors thank the MariClim (165112/S30) and COPOL (176073/S30) projects for assistance in gaining access to the birds and collecting the ticks, and the assistance of Kjetil Letto and Gry Gasbjerg with fieldwork. The comments of Rob Barrett on a draft manuscript were appreciated. Malin Daase assisted with the preparation of Fig. 1.

\section{References}

Boulinier T. \& Danchin E. 1996. Population trends in kittiwake Rissa tridactyla colonies in relation to tick infestation. Ibis 38, 326-334.

Coulson S.J. 2007. The terrestrial and freshwater invertebrate fauna of the High Arctic archipelago of Svalbard. Zootaxa 1448, 41-58.

Danchin E. 1992. The incidence of the tick parasite Ixodes uriae in kittiwake Rissa tridactyla colonies in relation to the age of the colony and a mechanism of infecting new colonies. Ibis 134, 134-141. 
Gabrielsen G.W. 2007. Levels and effects of persistent organic pollutants in Arctic animals. In J.B. Orbaek et al. (eds.): Arctic alpine ecosystems and people in a changing environment. Pp. 377-412. Berlin: Springer.

Gauthier-Clerc M., Clerquin Y. \& Handrich Y. 1998. Hyperinfestation by ticks Ixodes uriae: a possible cause of death in adult king penguins, a long-lived seabird. Colonial Waterbird 21, 229-233.

Larsson C., Comstedt P., Olsen B. \& Bergstrom S. 2007. First record of Lyme disease Borrelia in the Arctic. Vector Bourne Zoonotic Diseases 7, 453-456.

Lee R.E. \& Baust J.G. 1987. Cold-hardiness in the Antarctic tick Ixodes uriae. Physiological Zoology 60, 499-506.

Mangin S., Gauthier-Clerc M., Frenot Y., Gendner J.P. \& Le Maho Y. 2003. Ticks Ixodes uriae and the breeding performance of a colonial seabird king penguin Aptenodytes patagonicus. Journal of Avian Biology 34, 30-34.

McCoy K.D. 2001. Consequences of dispersal in host-parasite systems: population dynamics, genetic structure, and local adaptation of the seabird tick Ixodes uriae. PhD thesis. Pierre and Marie Curie University, Paris.

McCoy K.D. Chapuis E., Tirard C., Boulinier T., Michalakis Y., Le Bohec C., Le Maho Y. \& Gauthier-Clerc M. 2005. Recurrent evolution of host-specialized races in a globally distributed parasite. Proceedings of the Royal Society of London Series B 272, 2389-2395.

McCoy K.D., Tirard C. \& Michalakis Y. 2003. Spatial genetic structure of the ectoparasite Ixodes uriae within breeding cliffs of its colonial seabird host. Heredity 91, 422-429.

Mehl R., Bang C., Kjos-Hanssen B. \& Lie H. 1982. Mallophaga from Svalbard. Fauna Norvegica Series B 29, 19-23.

Mehl R. \& Traavik T. 1983. The tick Ixodes uriae (Acari, Ixodides) in seabird colonies in Norway. Fauna Norvegica Series B 30, 94-107.
Nunn M.A., Barton T.R., Wanless S., Hails R.S., Harris M.P. \& Nuttall P.A. 2006. Tick-borne Great Island Virus: (I) identification of seabird host and evidence for co-feeding and viraemic transmission. Parasitology 132, 233-240.

Sagerup K., Henriksen E.O., Skorping A., Skaare J.U. \& Gabrielsen G.W. 2000. Intensity of parasitic nematodes is associated with organochlorine levels in the glaucous gull (Larus hyperboreus). Journal of Applied Ecology 37, 532-539.

Sandvik H., Erikstad K.E., Barrett R.T. \& Yoccoz N.G. 2005. The effect of climate on adult survival in five species of North Atlantic seabirds. Journal of Animal Ecology 74, 817-831.

SCRIB 2007. Seabird Colony Registry of the Barents and White Seas. Unpublished database. Tromsø: Norwegian Polar Institute.

Staszewski V., McCoy K.D., Tveraa T. \& Boulinier T. 2007. Interannual dynamics of antibody levels in naturally infected long-lived colonial birds. Ecology 88, 3183-3191.

Strøm H. 2006. Birds of Svalbard. In K.M. Kovacs (ed.): Birds and mammals of Svalbard. Polarhåndbok 13. Pp. 86-191. Tromsø: Norwegian Polar Institute.

Strøm H. \& Bangjord G. 2004. The bird and mammal fauna of Svalbard. In P. Prestrud et al. (eds.): A catalogue of the terrestrial and marine animals of Svalbard. Skrifter 201. Pp. 123-135. Tromsø: Norwegian Polar Institute.

Wanless S., Barton T.R. \& Harris M.P. 1997. Blood hematocrit measurements of four species of North Atlantic seabirds in relation to levels of infestation by the tick Ixodes uriae. Colonial Waterbird 20, 540-544.

Wikel S.K. 1996. Host immunity to ticks. Annual Review of Entomology 41, 1-22. 